\title{
Sensibility analysis in the study of economic viability of a wind farm in the Canary Island. A case of study: 10 MW wind farm in Roque Prieto, Gáldar, Gran Canaria.
}

\author{
P. I. González Domínguez, G. Hernández Lezcano, M. Martínez Melgarejo, \\ A. Pulido Alonso, N. Angulo Rodríguez, J. C. Quintana Suárez, J. Romero Mayoral \\ Departamento de Ingeniería Eléctrica- Universidad de Las Palmas \\ Campus Universitario de Tafira, 35017 Las Palmas de Gran Canaria, Canary Islands (Spain) \\ Phone/Fax number: 0034928451871 / 0034928451874 \\ E-mail: pgonzalez@die.ulpgc.es; ghernandez@die.ulpgc.es; mmartinez@die.ulpgc.es; \\ apulido@die.ulpgc.es; nangulo@die.ulpgc.es; jquintana@die.ulpgc.es; jromero@die.ulpgc.es
}

\begin{abstract}
.
In this article, the economic viability of a typical wind farm of the Canary Islands is analyzed. The sensibility of the investment is analyzed as opposed to a series of factors which can change. Likewise, it is proved that exist technical and economic determinants that restrict the full development of the wind potential of a certain area, especially in the islands or places of complicated or slightly communicated geography.
\end{abstract}

\section{Key Words}

Wind farm, economic viability, sensibility analysis, Canary Islands.

\section{Introduction}

Energy is a vital component in the development of Canary Islands. In the first place, it is indispensable for the transport of people and merchandise. Secondly, it is indispensable for the industrial development. And thirdly, it is indispensable for the desalination of the sea water, so it is necessary for agriculture and the services. Also the power supplying is a key factor in a sector like the tourism, of extreme importance in the Canary Islands, and where the power demand includes the necessities of its infrastructures. The electricity provision is especially problematic in the islanded power systems.

They are fragmented markets. Canary Islands are constituted by six independent power systems. They have small dimensions and they are alienated of the big centers of supplying, which provokes electrical losses in percentage terms very top those who take place in the continental territory.

Also, in order to assure the power quality, the needs are superior in these territories to the continental ones. In many cases, the absence of proper energy resources, it drives unfailingly to a dependency much accused of the oil supplying or other primary energy sources.

Therefore, it is possible to affirm that the energy deficit in the community islands constitutes a serious obstacle to his economic development. The energy costs are bigger than other place of the European Community. To settle these structural shortcomings the renewable energies appear as partial solution to this problems.

The renewable energies help to improve the environment. The pollutants' emission comes down to the ambience. The Kyoto Protocol is fulfilled on the gas reduction of greenhouse effect and the four priorities of the European Union Sixth Environment Action Programme (nature, biodiversity, environment and health, and management of the natural resources and of the residues).

On the other hand, the renewable energies contribute to the diversification of the energy supply. They increase the safety power system, and what is more important, to be the only endogenous energy sources. The renewable energies increase the grade of self-sufficiency of the Canary Islands. The modification of the installed power in the electrical islanded systems is ruled by the Orden de 14 de octubre de 2004 of the Government of Canary Islands. 


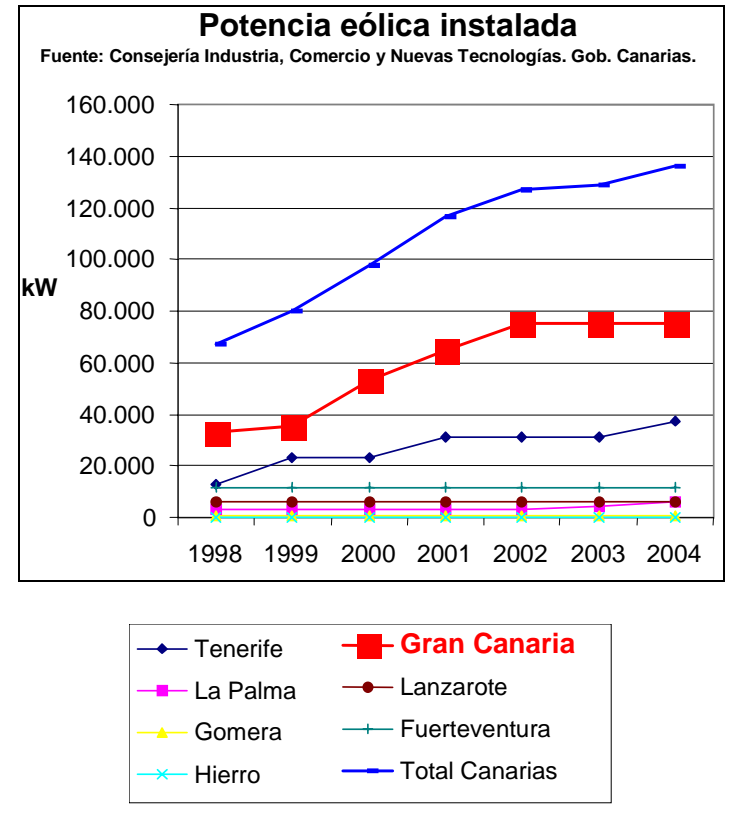

Fig. 1. Evolution of the wind power installed in Canary Islands. Source:Dirección General de Industria y Energía , Consejería de Industria, Comercio y Nuevas Tecnologías del Gobierno de Canarias. Diciembre 2004

The geographical distribution of the wind farms in Gran Canaria obeys the wind favourable conditions. They are the trade winds (alisios). They blow normally in North-East direction.

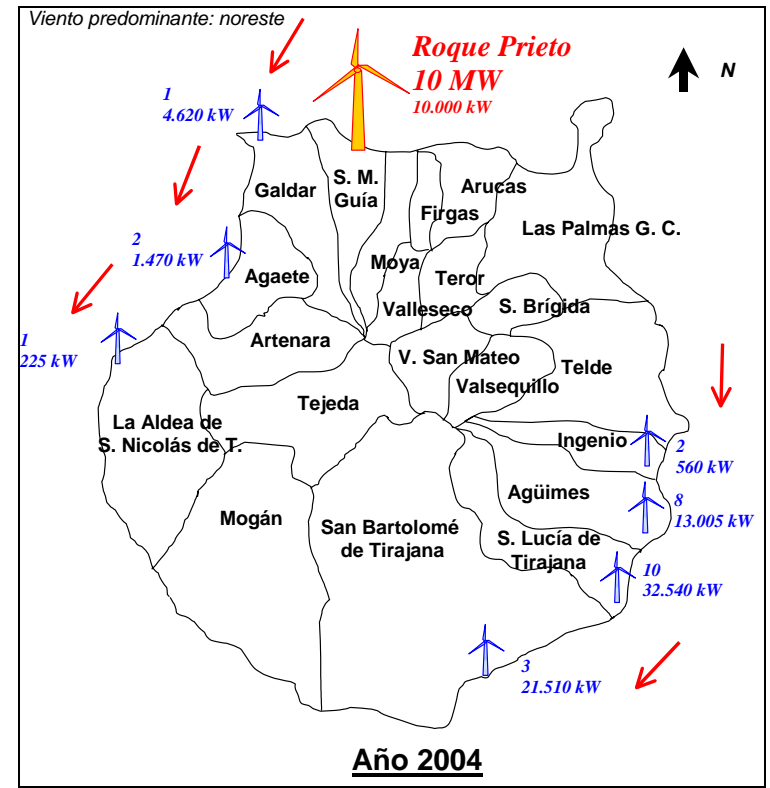

Fig. 2. Gran Canaria wind farm distribution. Source: authors of this paper.

\section{The Roque Prieto wind farm.}

The project Roque Prieto Wind Farm is submitted to the regulation that its is applied in the European Community, Spain and Canary Community, as well as the municipal norms that they affect to Santa Maria of Guía, Gran Canaria. The Orden 14 de Octubre de 2004 is a special regulation. It determines fundamentally the authorized dimensions of canary wind farm.

The technological frame will be determined by two fundamental aspects: The emplacement and the selection of the wind turbines. A series of criteria are taken for the selection of the wind turbines. These criteria are criteria of technical, administrative, economic and environmental order.

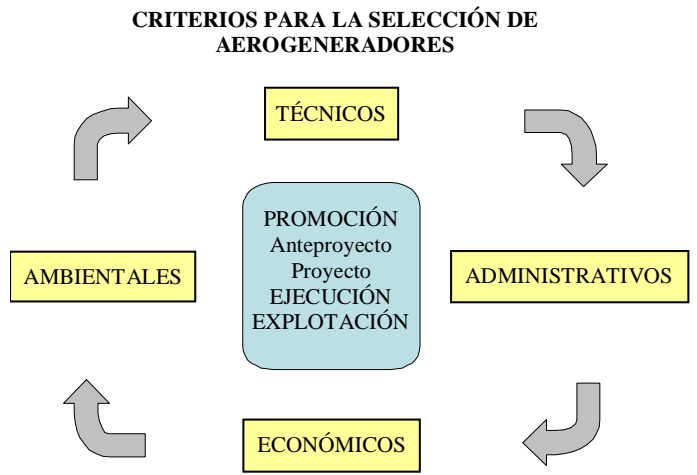

Fig. 3. Criteria to design a wind farm.

For the technical viability of the Roque Prieto wind farm the habitual parameters have been used to calculate: wind speed frequency curve, wind direction diagram, wind hourly change diagram, wind speed distribution, wind vertical change diagram, selection of the generator, wind penetration, quality power, etcetera. The adopted solution tries to obtain the biggest energy with the minimal occupation of soil, since the scarcity of the same one. This one is the principal restriction to install a wind farm in Canary Islands.

The criterion of wind farm election has been the year with major average speed of the wind (VMv) and the biggest piled up value of monthly speeds at a height of 10 meters. It has been believed that the area of Roque Prieto has a roughness class equal to 1.5

\begin{tabular}{|c|c|c|}
\cline { 2 - 3 } \multicolumn{1}{c|}{} & $\begin{array}{c}\text { VMv } \\
(\mathrm{m} / \mathrm{s})\end{array}$ & Acumulado \\
\hline $\mathbf{1 9 9 7}$ & 5,00 & 60,01 \\
\hline $\mathbf{1 9 9 8}$ & 6,39 & 76,63 \\
\hline $\mathbf{2 0 0 1}$ & 4,83 & 58,00 \\
\hline
\end{tabular}

Table 1. Election criterion for studied year. 
The wind turbines manufacturers have normalized the different heights hubs. In this study, the heights hubs overcome 67 meters are used. It is the maximum height hub till now installed in Canary Islands. This creates difficulties as the highway transport of the wind turbine, the availability of cranes with the sufficient height and accesses for the same ones on foot of the aerogenerator. The following normalized series of height hub have been studied: 74, 78, 90, 100 and 113 meters. In the election of the wind turbine owes fundamentally to his height hub (78 meters).

The commercial marks of aerogenerators studied are:

\begin{tabular}{|l|l|c|c|c|}
\hline Marca & Mod & $\begin{array}{c}\boldsymbol{h} \\
(\mathrm{m})\end{array}$ & $\begin{array}{c}\boldsymbol{D} \\
(\mathrm{m})\end{array}$ & $\begin{array}{c}\boldsymbol{P} \\
\mathrm{kW}\end{array}$ \\
\hline G & G-52 & 74 & 52 & 850 \\
\hline G & G-80 & 100 & 80 & 2.000 \\
\hline E & E-70 & 113 & 71 & 2.000 \\
\hline N-V & V52 & 74 & 52 & 850 \\
\hline N-V & V80 & 78 & 80 & 2.000 \\
\hline
\end{tabular}

Table 2. Types of studied aerogenerators.

Mark: GAMESA, ENERCON, NEGMICON-Vestas; $\boldsymbol{h}$ : height hub; $\boldsymbol{D}$ : diameter; $\boldsymbol{P}$ : power.

Every aerogenerator has the following values per year:

\begin{tabular}{|c|c|c|c|c|} 
Mod. & $\begin{array}{c}\text { EBA } \\
\text { MW }\end{array}$ & $\begin{array}{c}\text { ENA } \\
\text { MW }\end{array}$ & FC & HE \\
\hline G-52 & $3.361,3578$ & $3.113,9367$ & 0,4182 & $3.663,45$ \\
\hline G-80 & $8.744,4567$ & $8.100,7991$ & 0,4624 & $4.050,40$ \\
\hline E-70 & $8.578,1858$ & $7.946,7670$ & 0,4536 & $3.973,38$ \\
\hline V52 & $3.063,5617$ & $2.838,0606$ & 0,3812 & $3.338,89$ \\
\hline V80 & $8.387,5276$ & $7.770,1427$ & 0,4435 & $3.885,07$ \\
\hline
\end{tabular}

Table 3. Annual production of energy for every aerogenerator.

EBA: Gross annual energy; ENA: Net annual energy; FC: Capacity Factor; HE: Equivalent Hours; $\mathbf{N}$ : Aerogenerators number.

\section{The justification of the elected technology.}

Three-bladed wind turbines had been installed. Wind turbines have pitch angle of the blades for power regulation with variable wind speed. The elected emplacement has a medium-high wind speed rate $(6.43 \mathrm{~m} / \mathrm{s}$ at 10 meters of height). The elected aerogenerator is a NEGMICONVestas, model V80. It is equipped with OptiSpeed system. This system permits the rotor turn with variable speed. The rotor speed can change up to $60 \%$. The aerogenerator uses a doubly fed asynchronous generator.
The election of the aerogenerator NEGMICON-Vestas V80 owes fundamentally to his height hub (78 meters).

Other options would suppose a considerable height hub (100 and 113 meters), without experience of assembly in Canary Islands. It has serious problems of transport for highway and It is necessary to bring special cranes that would increase considerably the wind farm costs.

\section{The calculation of the electrical power production. The exposition and simulation of alternatives.}

Twice the diameter, in tier is the disposition of the wind turbines. The guidelines imposed by the Decreto 53/2003 de 30 de abril. It says the maximum number of wind turbines that can be placed in the emplacement is the following one:

\begin{tabular}{|c|c|c|c|c|c|}
\hline Mod & $\begin{array}{c}\boldsymbol{h} \\
(\mathrm{m})\end{array}$ & $\mathbf{N}$ & $\begin{array}{c}\text { ENA } \\
\text { MWh/año }\end{array}$ & FC & HE \\
\hline G-52 & 74 & 8 & $19.929,1946$ & 0,3346 & $2.930,76$ \\
\hline G-80 & 100 & 5 & $32.403,1964$ & 0,3699 & $3.240,32$ \\
\hline E-70 & 113 & 6 & $38.144,4815$ & 0,3629 & $3.178,71$ \\
\hline V52 & 74 & 8 & $18.163,5877$ & 0,3049 & $2.671,12$ \\
\hline V80 & $\mathbf{7 8}$ & $\mathbf{5}$ & $\mathbf{3 1 . 0 8 0 , 5 7 0 6}$ & $\mathbf{0 , 3 5 4 8}$ & $\mathbf{3 . 1 0 8 , 0 6}$ \\
\hline
\end{tabular}

Table 4. The wind farm options.

The adopted technical had been to put 5 aerogenerators NEGMICON-Vestas, model V80, $2.000 \mathrm{~kW}$ of rated power.

The elected emplacement for the wind farm can be considered as good or very good. A good emplacement has a capacity factor equal to $0.25-0.4$

\section{The profitability analysis of the investment.}

An underground evacuation line study was made. In case of an underground line had been adopted, the budget approximately had increased in $26 \%$.

The substantial budgetary difference it was decided an aerial evacuation line. Therefore it was considered to be an initial investment, including the budgetary provision for the dismantling of the wind farm, the quantity of $12.658 .950 €$.

The income for sale of the energy produced in the wind farm Roque Prieto will answer to the following expression:

$$
I=P \cdot T_{m r}+C_{e r} \cdot P \cdot T_{m r}=P \cdot T_{m r} \cdot(1+C e r)
$$


I: Income for sale of the energy $(€) ; \boldsymbol{P}$ : Electrical energy production $(\mathrm{kWh}) ; \boldsymbol{T}_{\boldsymbol{m} r}$ : electrical yardstick rate $(€ / \mathrm{kWh}) ; \boldsymbol{C}_{\boldsymbol{e r}}$ : Reactive energy complement (4\% of total income).

Since 2010 a 3\% increment of the electrical yardstick rate is considered. With these conditions and after deducting all the foreseeable expenses of the wind farm, the information of economic profitability is the following ones:

\begin{tabular}{|l|r|l|}
\hline NPV: & $10.231 .121,97$ & $€$ \\
\hline IRR: & 7,71 & $\%$ \\
\hline PAYBACK: & 13 & years \\
\hline
\end{tabular}

Table 5. Investment profitability.

This profitability is comparable [1] with, a standardized wind farm of $15 \mathrm{MW}$ and $36 \mathrm{GWh} /$ year of electrical production and with an investment of $12.801 .557 €$, which investment profitability is the following one:

\begin{tabular}{|l|r|l|}
\hline NPV: & $3.792 .386,38$ & $€$ \\
\hline IRR: & 6,8 & $\%$ \\
\hline PAYBACK: & 10,1 & años \\
\hline
\end{tabular}

Table 6 Investment profitability. Source: IDAE

NPV: Net Present Value (Spanish: VAN); IRR: Investment Internal Rate of Returns (Spanish: TIR).

Slight differences, due to greater costs of installation in the islands can be appreciated fundamentally that in continental territory.

\section{The analysis of sensibility.}

The analysis that has taken place is one-dimensional (a single parameter varying and the other are constants). Sensitivity must become with respect to the most uncertain parameter. The parameters with greater uncertainty have studied, than they are the following ones: capacity factor, bank rate, operation and maintenance, yardstick rate and initial investment.

\begin{tabular}{|l|c|}
\hline PARAMETER & $\begin{array}{c}\text { PROBABLE } \\
\text { VARIATION RANGE }\end{array}$ \\
\hline FC & $\pm 10 \%$ \\
\hline TI & $3,12 \% \leftrightarrow 5,00 \%$ \\
\hline O\&M & $\pm 10 \%$ \\
\hline TA & $-10 \% \leftrightarrow 20 \%$ \\
\hline INI & $-20 \% \leftrightarrow 50 \%$ \\
\hline
\end{tabular}

Table 7. Probable variation range of economic parameters.

FC: Capacity factor; TI: Bank rate; O\&M: Operation \& Maintenance; TA: Yardstick rate; INI: Initial investment
The dependent variables analyzed in the sensibility analysis are the NPV, the IRR and the PAYBACK. 15 possible stages have been proposed. The range changes from the lowest level to the highest level. The obtained sensibilities have been the following ones:

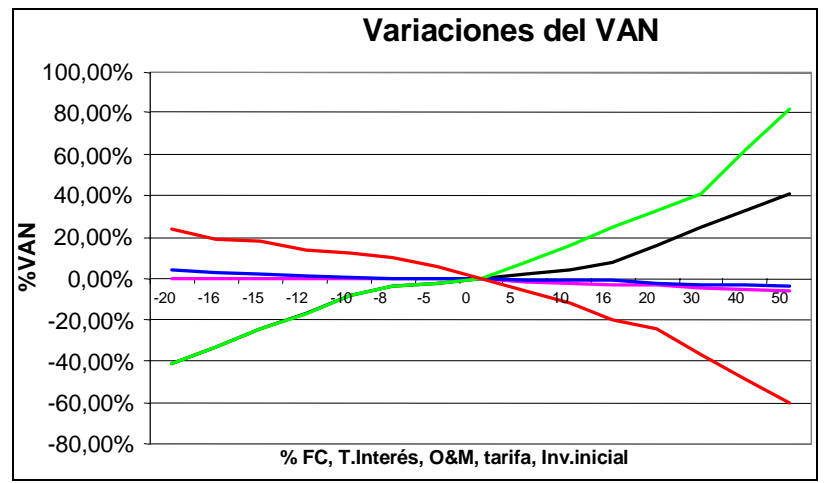

Fig. 4. NPV porcentage changes.

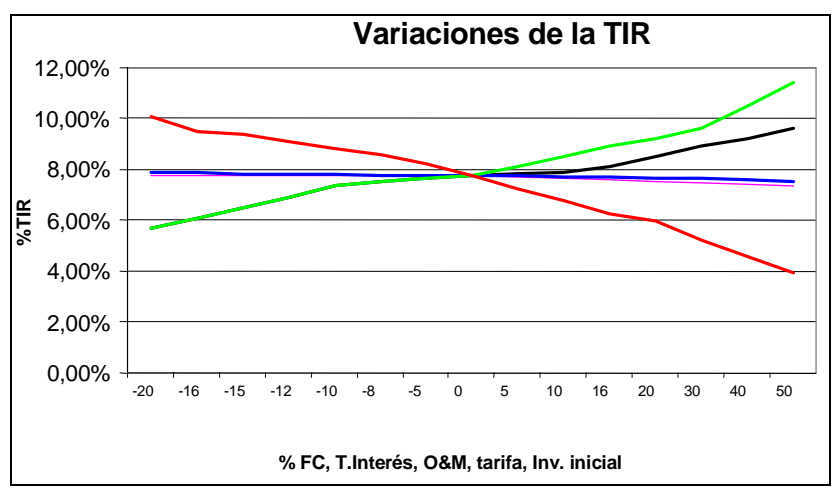

Fig. 5. IRR porcentage changes.

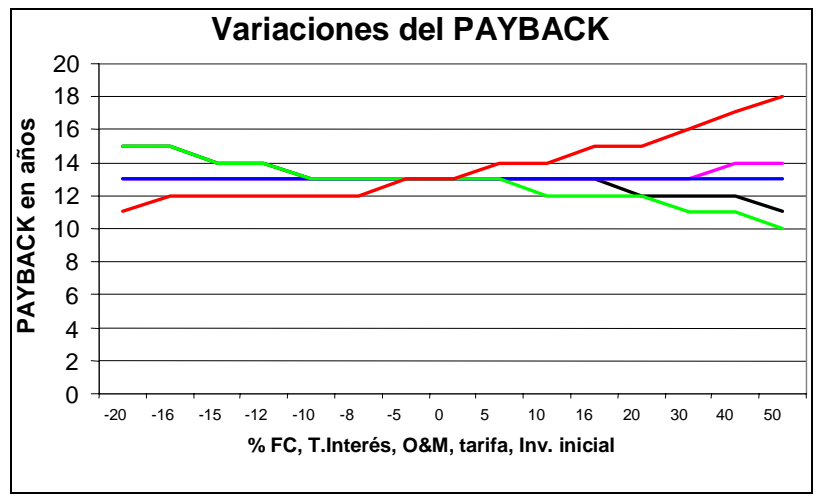

Fig. 6. PAYBACK porcentaje change.

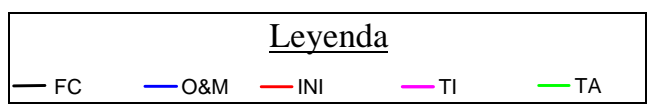

The yardstick rate, capacity factor and initial investment changes produce the biggest changes in the graphs. All this indicates that the future profitability of the project is determined by a correct engineering and the maintenance of 
the pricing current frame. It is possible to appreciate that the change of bank rate affects less to profitability than the changes in the cost of operation and maintenance. NPV, IRR and PAYBACK have a similar sensibility. The PAYBACK is minor than 20 years. That is the expected life of the project.

\section{The evaluation of the risk.}

The analysis of sensibility only shows the behaviour of the investment when it changes only one of his parameters. To verify the behaviour of the investment with simultaneous changes of several parameters, the analysis of risk is necessary. The following scenarios have been considered: WORST-CASE SCENARIO (In this scenario are considered the most unfavourable conditions and they have major probability of happening), NEUTRAL-CASE SCENARIO (scenario used in the calculations for this study) and BEST-CASE SCENARIO (In this scenario are considered the most favourable conditions and they have major probability of happening).

The results for the different scenarios are summed up in the attached table.

\begin{tabular}{|l|r|r|r|}
\hline \multicolumn{1}{|c|}{ Scenario: } & \multicolumn{1}{c|}{$\mathbf{~}$} & \multicolumn{1}{c|}{$\mathbf{N}$} & \multicolumn{1}{c|}{ W } \\
\hline HE: & $3.294,54$ & $3.108,06$ & $2.921,58$ \\
\hline ENA(MWh/año): & $32.945,43$ & $31.080,57$ & $29.215,76$ \\
\hline INI (M€): & 11,393 & 12,658 & 14,754 \\
\hline INI (\%): & $(-) 10,00$ & 0,00 & $(+) 16,55$ \\
\hline TI (\%): & 3,220 & 3,220 & 4,500 \\
\hline O\&M (\%): & 10,00 & 10,00 & 10,40 \\
\hline TA (€/kWh): & 0,075221 & 0,073030 & 0,073396 \\
\hline$\Delta$ TA.(\%): & 3,00 & 0,00 & 0,50 \\
\hline NPV (M€): & 15,335 & 10,231 & 5,684 \\
\hline IRR (\%): & 10,63 & $7,71 \%$ & 5,10 \\
\hline PAYBACK (years): & 11 & 13 & 16 \\
\hline
\end{tabular}

Table 8. Risks of economic investment for Roque Prieto wind farm.

\section{Conclusions}

In islanded power systems, one of the principal restrictions is the penetration rate of wind power in the network. Nevertheless there is another series of specific determinants to determine the optimal power to install in the wind farm.

One of the determinant factors in the islanded power systems is the scarcity of available soil with usable wind potential; not always it is correct to maximize the power to install increasing the height hub of the wind turbines.
Factors such as the accesses to the wind farm, the scarcity of the transports or the installation of the wind turbines, they can be decisive in the economic viability of the project.

If the wind farm is going to settle in developing countries, it is convenient to do a detailed study of foreign factors of the proper wind farm, such as accesses, technological availability of teams of transport and assembly for big heights of wind turbine hub, the training of operation and maintenance human team, etc.

\section{References}

[1] V. Olmos García, J.J. Romero Zamora yB. Benavides González-Camino, Análisis económico de un parque eólico, Instituto para la Diversificación y Ahorro de la Energía (IDAE), 2000, pp 49.

[2] Suárez Suárez, Adrés S. Decisiones óptimas de inversión y financiación en la empresa. Madrid (1991): Ediciones Pirámides, SA, ISBN 84-368-0323-X (libro)

[4] Villarubia, Miguel. Energía eólica. Barcelona (2004): Editorial CEAC, ISBN 84-329-1062-7 (libro).

[5] APPA. Libro blanco de la generación eléctrica en España. La visión de los productores de energías renovables. Editorial APPA. Marzo, 2005.

[6] Olmos García, Víctor y Otros. Manual de energía eólica. Cuadernos de energías renovables. Madrid (1992): Editorial IDEA, ISBN 84-86850-35-5 (libro).

[7] Rodríguez Amenedo, José Luis y Otros. Sistemas eólicos de producción de energía eléctrica. Madrid (2003): Editorial Rueda, SL, ISBN 84-7207-139-1 (libro).

[8] Danish Wind Industry Association. (2005). English. Español. La Visita Guiada. [On-line], http://www.windpower.org/, (acceso 2006).

[9] Dirección General de Industria. (2005). Guía de Proyectos.[On-line], http://www.gobiernodecanarias.org/industria/, (acceso 2006).

[10] ENERCON. Energy for the Wolrd (2005). Wind turbines.

[On-line] http://www.enercon.de/en/_home.htm, (acceso 2005).

[11] GAMESA. (2005). Productos. [On-line], http://www.gamesa.es/gamesa/index.html, (acceso 2005).

[13] NEGMICON-VESTAS. (2005). Products. [On-line], http://www.vestas.com/uk/Home/index.asp, (acceso 2005).

[14] Ministerio de Industria, Turismo y Comercio. (2005). Legislación. Publicaciones. Indicadores, Estadísticas e Informes. [On-line]. http://www.min.es, (acceso 2006).

[15] The European Wind Energy Association. (2005). Products. [On-line], http://www.ewea.org/, (acceso 2006).

[16] REE. (2005). El Sistema Eléctrico Español 2004. [Online], http://www.ree.es/, (acceso 2006). 
[17] DECRETO 53/2003, de 30 de abril, por el que se regula la instalación y explotación de los parques eólicos en el ámbito de la Comunidad Autónoma de Canarias.

[18] ORDEN de 14 de octubre de 2004, por la que se convoca concurso público para la asignación de potencia en la modalidad de instalación de nuevos parques eólicos destinados a verter toda la energía en los sistemas eléctricos insulares canarios. 